J. Dairy Sci. 96:1085-1089

http://dx.doi.org/10.3168/jds.2012-5783

(c) American Dairy Science Association ${ }^{\circledR}, 2013$.

\title{
Short communication: Acute but transient increase in serum insulin reduces messenger RNA expression of hepatic enzymes associated with progesterone catabolism in dairy cows
}

\author{
F. V. R. Vieira, ${ }^{*}$ R. F. Cooke,† A. C. Aboin, ${ }^{*}$ P. Lima, $\ddagger$ and J. L. M. Vasconcelos ${ }^{* 1}$ \\ *Departamento de Produção Animal, Faculdade de Medicina Veterinária e Zootecnia - UNESP, Botucatu, São Paulo 18618-000, Brazil \\ †Oregon State University, Eastern Oregon Agricultural Research Center, Burns 97720 \\ ‡Departamento de Fisiologia, Instituto de Biociências, Universidade Estadual Paulista "Júlio de Mesquita Filho" (UNESP), Botucatu, \\ São Paulo 18618-000, Brazil
}

\section{ABSTRACT}

The objective of this experiment was to evaluate the effects of glucose infusion on serum concentrations of glucose, insulin, and progesterone (P4), as well as mRNA expression of hepatic CYP2C19 and CYP3A4 in nonlactating, ovariectomized cows in adequate nutritional status. Eight Gir $\times$ Holstein cows were maintained on a low-quality Brachiaria brizantha pasture with reduced forage availability, but they individually received, on average, $3 \mathrm{~kg} / \mathrm{cow}$ daily (as fed) of a cornbased concentrate from $\mathrm{d}-28$ to 0 of the experiment. All cows had an intravaginal P4-releasing device inserted on $\mathrm{d}-14$, which remained in cows until the end of the experiment (d 1). On d 0, cows were randomly assigned to receive, in a crossover design containing 2 periods of $24 \mathrm{~h}$ each (d 0 and 1), (1) an intravenous glucose infusion (GLUC; $0.5 \mathrm{~g}$ of glucose $/ \mathrm{kg}$ of BW, over a 3 -h period) or (2) an intravenous saline infusion (SAL; $0.9 \%$, over a 3 -h period). Cows were fasted for $12 \mathrm{~h}$ before infusions, and they remained fasted during infusion and sample collections. Blood samples were collected at 0,3 , and $6 \mathrm{~h}$ relative to the beginning of infusions. Liver biopsies were performed concurrently with blood collections at 0 and $3 \mathrm{~h}$. After the last blood collection of period 1 , cows received concentrate and returned to pasture. Cows gained BW $(16.5 \pm 3.6 \mathrm{~kg})$ and $\mathrm{BCS}(0.08 \pm 0.06)$ from $\mathrm{d}-28$ to 0 . Cows receiving GLUC had greater serum glucose and insulin concentrations at $3 \mathrm{~h}$ compared with SAL cohorts. No treatment effects were detected for serum $\mathrm{P} 4$ concentrations, although mRNA expression of CYP2C19 and CYP3A4 after the infusion period was reduced for cows in the GLUC treatment compared with their cohorts in the SAL treatment. In conclusion, hepatic CYP3A4 and CYP2C19 mRNA expression can be promptly modu-

Received May 29, 2012.

Accepted October 7, 2012.

${ }^{1}$ Corresponding author: vasconcelos@fmvz.unesp.br lated by glucose infusion followed by acute increases in circulating insulin, which provides novel insight into the physiological mechanisms associating nutrition and reproductive function in dairy cows.

Key words: dairy cow, glucose infusion, hepatic enzyme, progesterone

\section{Short Communication}

During the last few decades, milk production per dairy cow increased, whereas reproductive efficiency decreased (Lucy, 2001). Given that nutrition substantially affects productive and reproductive functions (Butler, 2005), nutritional strategies that promote milk production and concurrently benefit the reproductive efficiency of dairy cows are warranted. Moreover, the development of such strategies is dependent on a recognition of physiological mechanisms that associate nutrition with reproductive functions in dairy cattle. As an example, nutrition has been shown to regulate cattle reproduction, at least partially, via circulating hormones and metabolites such as glucose and insulin (Wettemann et al., 2003).

Insulin modulates circulating concentrations of progesterone (P4), a steroid required for the establishment and maintenance of pregnancy (Spencer and Bazer, 2002), by stimulating luteal P4 synthesis (Spicer and Echternkamp, 1995) and alleviating hepatic P4 catabolism by CYP2C and CYP3A enzymes (Murray, 1991). Lemley et al. (2008) reported that lactating dairy cows receiving a hyperinsulinemic-euglycemic clamp for $96 \mathrm{~h}$ had reduced mRNA expression of CYP2C19 and CYP3A4 at the end of the infusion period compared with cohorts receiving saline. The same authors also reported that periparturient dairy cows receiving daily propylene glycol drenches for $35 \mathrm{~d}$ had reduced mRNA expression of CYP3A4 compared with cohorts drenched with water. Moreover, our research group recently reported that intravenous glucose infusion for $3 \mathrm{~h}$ promptly increased circulating concentrations of insulin 
and $\mathrm{P} 4$ in ovariectomized cows in positive nutritional status and supplemented with exogenous P4 (Vieira et al., 2010), suggesting that acute increases in circulating insulin are sufficient to affect hepatic P4 catabolism when nutrient intake is adequate (Vieira et al., 2010). To further investigate this outcome, the objective of the present experiment was to evaluate serum concentrations of glucose, insulin, and $\mathrm{P} 4$, as well as mRNA expression of hepatic CYP2C19 and CYP3A4, in nonlactating dairy cows maintained in adequate nutritional status and receiving or not receiving an intravenous glucose infusion.

This experiment was conducted at the São Paulo State University, Lageado Experimental Station, located in Botucatu, São Paulo, Brazil. The animals used were cared for in accordance with the practices outlined in the Guide for the Care and Use of Agricultural Animals in Agricultural Research and Teaching (FASS, 1999). Eight nonlactating, nonpregnant, and ovariectomized Gir $\times$ Holstein cows $(\mathrm{BW}=627 \pm 32 \mathrm{~kg}$; BCS $=3.5 \pm 0.1$; Wildman et al., 1982) were maintained on Brachiaria brizantha pastures with low forage quality (average of $47 \% \mathrm{TDN}, 7.6 \% \mathrm{CP}$, and $60.0 \% \mathrm{NDF}$, DM basis) and availability (average of $5.0 \mathrm{~kg}$ of DM/ cow daily) from d -28 to 0 of the experimental period. Cows received daily (as-fed basis), at $1200 \mathrm{~h}, 2 \mathrm{~kg} / \mathrm{cow}$ of a supplemental concentrate from d -28 to -15 , and $4.5 \mathrm{~kg} /$ cow of the same concentrate from d -14 to 0 . Supplement was offered individually to cows through self-locking head gates. Cows also received a mineral and vitamin $\operatorname{mix}(7.7 \% \mathrm{Ca}, 4.0 \% \mathrm{P}, 3.0 \% \mathrm{Na}, 0.20 \%$ $\mathrm{K}, 0,20 \% \mathrm{Mg}, 2.0 \% \mathrm{~S}, 0.002 \% \mathrm{Co}, 0.03 \% \mathrm{Cu}, 0.002 \%$ I, $0.02 \% \mathrm{Mn}, 0.13 \% \mathrm{Zn}$, and $0.02 \% \mathrm{~F}$ ) and water ad libitum throughout the experiment. The supplemental concentrate consisted of (DM basis) $66.0 \%$ ground corn, $27.7 \%$ soybean meal, $2.5 \%$ mineral mix $(18 \% \mathrm{Ca}$, $10.7 \% \mathrm{Na}, 8 \% \mathrm{P}, 1.2 \% \mathrm{~S}, 0.5 \% \mathrm{Mg}, 0.13 \% \mathrm{Cu}, 0.007 \%$ Co, and $0.007 \%$ I), $2.5 \%$ limestone, and $1.3 \%$ urea. Nutritional content of the concentrate was estimated to be (DM basis) $78 \%$ TDN, $22.5 \% \mathrm{CP}$, and $12.9 \% \mathrm{NDF}$. From d -28 to 0 , forage mass was evaluated weekly according to the techniques described by Vendramini et al. (2008). Forage and concentrate samples were collected weekly and analyzed for nutritional content by a bromatology laboratory (São Paulo State University, Botucatu, Brazil).

On d 0, cows were randomly assigned to receive, in a crossover design containing 2 periods of $24 \mathrm{~h}$ each (d 0 and 1), (1) an intravenous glucose infusion (0.5 $\mathrm{g} / \mathrm{kg}$ of BW; GLUC) and (2) an intravenous saline infusion (SAL; equivalent volume as GLUC). Before the beginning of each period, cows were fasted for 12 $\mathrm{h}$, beginning at $1800 \mathrm{~h}$ on the day before each period. Immediately before infusions, all cows were fitted with indwelling jugular catheters (Curley et al., 2008). Treatments (GLUC or SAL) were administered via catheters over a period of $3 \mathrm{~h}$ (on average $36 \mathrm{~mL} / \mathrm{min}$ ); cows in the GLUC treatment received a $5 \%$ (wt/vol) glucose solution (90:10 solution of physiological saline and Glicose 50\%; Laboratório Prado S.A., Curitiba, Brazil) according to their BW, whereas cows in the SAL treatment received a comparable volume of physiological saline $(0.9 \%)$. Catheters were removed after the end of infusions.

Cow BW and BCS were assessed at d $-28,-14$, and -1 to ensure that cows were in adequate nutritional status during the experiment. From d -28 to -15 , all cows were inserted with a previously used (third use) intravaginal P4-releasing device (CIDR, originally containing 1.9 g of P4; Pfizer Animal Health, São Paulo, Brazil) to initially expose and adapt cows to exogenous $\mathrm{P} 4$. Cows received a new P4-releasing device on $\mathrm{d}$ -14 , which remained in the cows until the end of the experiment. Blood samples were collected via jugular venipuncture at 0 (immediately before), 3 , and $6 \mathrm{~h}$ relative to the beginning of the infusion $(0 \mathrm{~h})$. Liver biopsies were collected concurrently with blood sampling at 0 and $3 \mathrm{~h}$, according to the procedure described by Arthington and Corah (1995). During each biopsy, the incision was made $2 \mathrm{~cm}$ apart from any previous incision to prevent collection of damaged tissue. After the last blood collection of period 1, cows received the supplementation and returned to pasture. Cows were fasted before infusions to prevent any confounding effects between feed intake and infusion treatments on circulating concentrations of P4 (Vasconcelos et al., 2003). Blood samples were collected into commercial blood collection tubes (Vacutainer, $10 \mathrm{~mL}$; Becton Dickinson, Franklin Lakes, NJ), placed immediately on ice, maintained at $4^{\circ} \mathrm{C}$ for $24 \mathrm{~h}$ to allow clotting, and centrifuged at $3,000 \times g$ for $30 \mathrm{~min}$ at $4^{\circ} \mathrm{C}$ for serum collection. Harvested serum was stored frozen at $-20^{\circ} \mathrm{C}$ until further processing. A quantitative colorimetric kit was used to determine concentrations of glucose (Katal Biotecnologica Ind. Com. Ltda., Belo Horizonte, Brazil). Concentrations of $\mathrm{P} 4$ and insulin were determined using a Coat-A-Count Kit solid-phase ${ }^{125}$ I RIA (DPC Diagnostic Products Inc., Los Angeles, CA), as previously reported by our group (Moriel et al., 2008). All samples were analyzed within 1 assay for each hormone. The intraassay coefficient of variation was $5.8 \%$ for $\mathrm{P} 4$ and $6.9 \%$ for insulin.

Immediately after collection, liver samples (average $100 \mathrm{mg}$ of tissue, wet weight) were placed in $1 \mathrm{~mL}$ of RNA stabilization solution (RNAlater; Ambion Inc., Austin, TX), maintained at $4^{\circ} \mathrm{C}$ for $24 \mathrm{~h}$, and stored at $-20^{\circ} \mathrm{C}$. Total RNA was extracted from tissue samples using a TRIzol Plus RNA Purification Kit (Invitrogen, 
Carlsbad, CA). Quantity and quality of isolated RNA were assessed via UV absorbance (NanoDrop 1000 spectrophotometer; Thermo Fisher Scientific, Wilmington, $\mathrm{DE})$ at $260 \mathrm{~nm}$ and a 260:280 $\mathrm{nm}$ ratio, respectively (Fleige and Pfaffl, 2006). Extracted RNA was stored at $-80^{\circ} \mathrm{C}$ until further processing. Extracted RNA $(2.5$ $\mu \mathrm{g})$ were incubated at $37^{\circ} \mathrm{C}$ for $30 \mathrm{~min}$ in the presence of RNase-free DNase (New England Biolabs Inc., Ipswich, MA) to remove contaminant genomic DNA. After inactivating the DNase $\left(75^{\circ} \mathrm{C}\right.$ for $\left.15 \mathrm{~min}\right)$, samples were reverse-transcribed using SuperScript III (Invitrogen, Carlsbad, CA) with poly-T oligonucleotide (12 to 18 nucleotides). Real-time PCR was completed using the SYBR Green PCR Master Mix (Applied Biosystems, Foster City, CA) and specific primer sets $(25 \mathrm{ng} / \mathrm{mL}$; Table 1), with an ABI Prism 7500 Sequence Detection System (Applied Biosystems). Amplification was optimal at an annealing temperature of $60^{\circ} \mathrm{C}$, and theoretical yields of cyclophilin-A, CYP2C19, and CYP3A4 were $102,97.5$, and $101 \%$, respectively. The identity of amplicons was confirmed by analysis of their size by electrophoresis on 1.5\% agarose gel and the dissociation curve. Responses were quantified based on the threshold cycle (CT), the number of PCR cycles required for target amplification to reach a predetermined threshold. All CT responses were normalized to cyclophilin-A CT examined in the same sample and at the same time as targets. Results are expressed as the relative fold change $\left(2^{-\Delta \Delta \mathrm{CT}}\right.$; Ocón-Grove et al., 2008).

Data were analyzed using the MIXED procedure of SAS (SAS Institute Inc., Cary, NC) and the Satterthwaite approximation to determine the denominator degrees of freedom for the tests of fixed effects. The model statement used for BW and BCS change contained the effects of day. The model statement used for serum and liver data contained the effects of treatment, hour (serum measurements only), and the resultant interaction, in addition to values obtained immediately before infusion $(0 \mathrm{~h})$ as an independent covariate. All data were analyzed using cow as the random variable. The specific terms for repeated measures were day for
BW and BCS change and hour for serum variables, and the covariance structure used was autoregressive, which provided the best fit for these analyzes according to the Akaike information criterion. All results are reported as least squares means and separated using the least significant difference. Significance was established as $P$ $\leq 0.05$ and tendencies as $P>0.05$ and $\leq 0.10$.

Cow BW increased $(P<0.01)$, whereas BCS did not change $(P=0.17)$ from $\mathrm{d}-28$ to $0(627$ vs. $644 \mathrm{~kg}$ of BW, SEM = 33, and 3.53 vs. 3.60 of BCS, SEM = 0.16 ; respectively), demonstrating that all cows were in adequate nutritional status during the experimental period and before the treatment application. As expected based on the experimental design, a treatment $\times$ time interaction was detected $(P<0.01)$ for serum glucose and insulin because cows in the GLUC treatment had greater concentrations of these substances at $3 \mathrm{~h}$ after the beginning of infusion compared with cows in the SAL treatment (Figure 1). Similarly, Vieira et al. (2010) reported greater serum glucose concentrations in dairy cows receiving a similar intravenous glucose infusion compared with cohorts receiving saline, whereas insulin is synthesized and secreted mainly in response to blood glucose concentrations (Nussey and Whitehead, 2001).

No treatment effects were detected $(P=0.73)$ for serum $\mathrm{P} 4$ concentrations ( 1.54 and $1.49 \mathrm{ng} / \mathrm{mL}$ for cows in the GLUC and SAL treatments, respectively; SEM $=0.11$ ), differing from the results reported by Vieira et al. (2010). One may speculate that serum insulin concentrations achieved herein upon glucose infusion, which were reduced compared with those reported by Vieira et al. (2010), were not sufficient to affect serum $\mathrm{P} 4$ concentrations. Yet it is important to note that this experiment was mainly designed to evaluate treatment effects on hepatic mRNA expression of CYP2C19 and CYP3A4, whereas blood samples were not collected as frequently as by Vieira et al. (2010) to properly assess potential treatment effects on serum P4. Nevertheless, mRNA expression of CYP2C19 and CYP3A4 upon the infusion period was reduced $(P=0.05$ and 0.01 , respectively) in cows in the GLUC treatment compared with

Table 1. Primer sequences, annealing temperatures, efficiency, and reference for all gene transcripts analyzed by real-time reverse-transcription PCR

\begin{tabular}{llll}
\hline Gene & Primer sequence & Accession no. & Source \\
\hline CYP2C19 & & NM_001109792 & Lemley et al. (2008) \\
Forward & 5'-TATGGACTCCTGCTCCTGCT-3' & & Lemley et al. (2008) \\
Reverse & 5'-CATCTGTGTAGGGCATGCAG-3' & BT030557 & Machado et al. (2009) \\
CYP3A4 & 5'-GTGCCAATCTCTGTGCTTCA-3' & & \\
Forward & 5'-CCAGTTCCAAAAGGCAGGTA-3' & NM_178320.2 & \\
Cyclophilin-A & 5'-GCCATGGAGCGCTTTGG-3' & & \\
$\quad$ Forward & 5'-CCACAGTCAGCAATGGTGATCT-3' & & \\
Reverse & & &
\end{tabular}



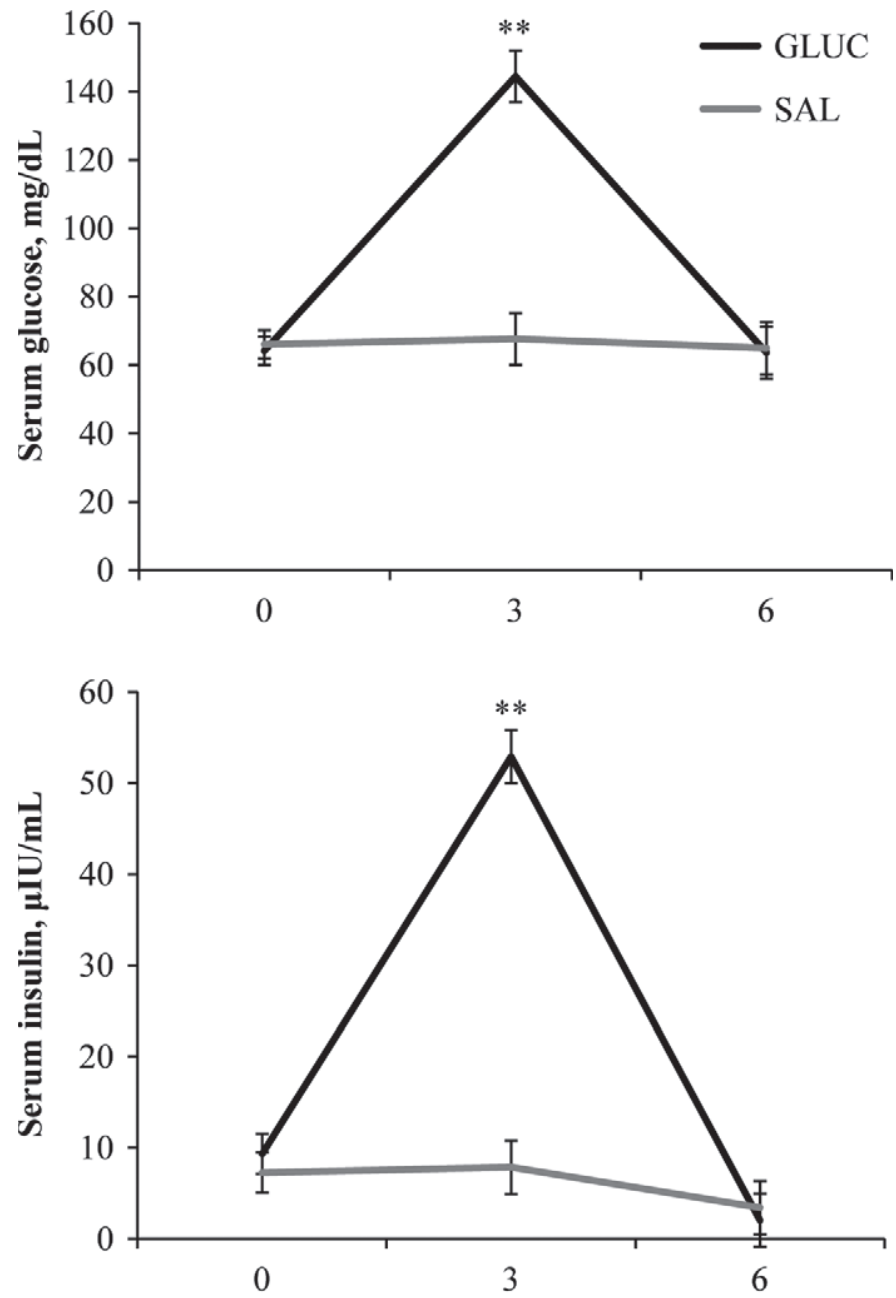

Hour relative to beginning of treatment infusion

Figure 1. Serum concentrations of glucose and insulin in nonlactating cows infused intravenously with a $5 \%$ glucose solution (GLUC; $0.5 \mathrm{~g}$ of glucose $/ \mathrm{kg}$ of BW, infused on average at $36 \mathrm{~mL} / \mathrm{min}$ over a 3 -h period) or with physiological saline (SAL; $0.9 \%$ solution infused on average at $36 \mathrm{~mL} / \mathrm{min}$ over a 3 -h period). Treatments were infused immediately after blood sampling at $\mathrm{h} 0$, which served as covariates, A treatment $\times$ time interaction was detected for both variables $(P<$ $0.01)$. Treatment comparison within time: ${ }^{* *} P<0.01$.

their cohorts in the SAL treatment (Figure 2), supporting our main theory and previous research reporting inhibitory effects of insulin on hepatic expression of $\mathrm{P} 4$ catabolic enzymes (Lemley et al., 2008, 2010). More specifically, insulin regulates coactivators, such as peroxisome proliferator-activated receptor- $\gamma$ coactivator $1 \alpha$, which directly modulate transcription factors on promoter regions of the CYP3A4 and CYP2C19 genes and consequent mRNA expression of these enzymes (Martínez-Jiménez et al., 2006; Kim and Novak, 2007).

The outcomes reported herein are novel because they demonstrate that acute and transient increases in circulating insulin, upon intravenous glucose infu-

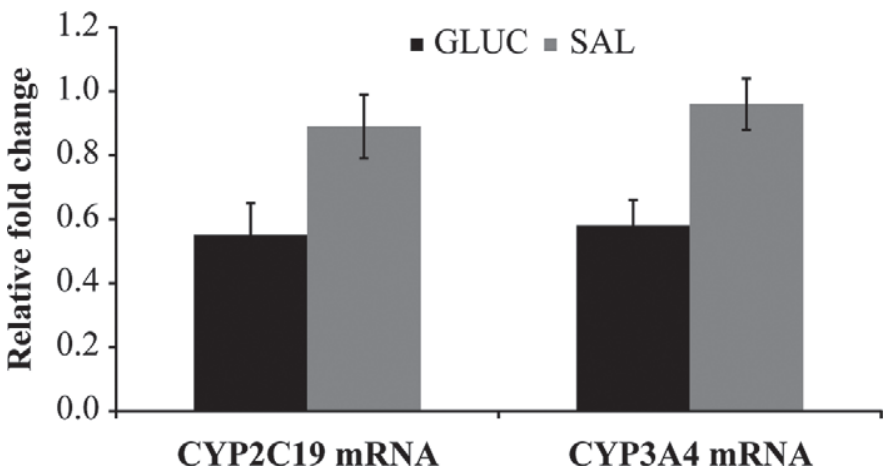

Figure 2. Expression of hepatic CYP2C19 and CYP3A4 mRNA, as the relative fold change (Ocón-Grove et al., 2008), of nonlactating cows infused intravenously with a $5 \%$ glucose solution (GLUC; $0.5 \mathrm{~g}$ of glucose $/ \mathrm{kg}$ of BW, infused on average at $36 \mathrm{~mL} / \mathrm{min}$ over a $3-\mathrm{h}$ period) or with physiological saline (SAL; $0.9 \%$ solution infused on average at $36 \mathrm{~mL} / \mathrm{min}$ over a 3 -h period). Treatments were infused immediately after liver sampling at $\mathrm{h} 0$, which served as covariates. A treatment effect was detected for mRNA expression of both enzymes $(P=0.05$ and 0.01 for CYP2C19 and CYP3A4, respectively).

sion, promptly reduce mRNA expression of hepatic CYP3A4 and CYP2C19 in dairy cows in adequate nutritional status. This mechanism supports previous data from our group reporting that nonlactating dairy cows with elevated serum insulin concentration had a delayed decrease in serum P4 upon feed intake, perhaps because of a transient decrease in hepatic $\mathrm{P} 4$ catabolism, compared with cohorts with reduced serum insulin (Moriel et al., 2008). It is also important to note that other research groups reporting inhibitory effects of insulin on hepatic expression of $\mathrm{P} 4$ catabolic enzymes evaluated dairy cows receiving insulinogenic treatments for longer periods of time (Lemley et al. 2008, 2010). Moreover, our research group (Vieira et al., 2010) reported that dairy cows in negative nutrient status, such as the periparturient and early-lactation dairy cows used by Lemley et al. (2008), did not experience altered serum P4 concentrations upon a 3-h glucose infusion and subsequent acute increase in serum insulin. These outcomes suggest that cows in negative nutritional status may require prolonged increases in glucose and subsequent insulin concentrations to experience altered hepatic P4 catabolism. Hence, additional research is still required to comprehend the differences in CYP2C19 and CYP3A4 gene expression by circulating insulin according to cow nutritional status.

In conclusion, cows in adequate nutrient status and administered $0.5 \mathrm{~g} / \mathrm{kg}$ of BW of glucose for $3 \mathrm{~h}$ had greater serum insulin concentrations and reduced hepatic CYP3A4 and CYP2C19 mRNA expression upon glucose infusion compared with cohorts infused with saline. Therefore, hepatic expression of P4 catabolic enzymes can be promptly modulated by acute increases 
in circulating insulin upon intravenous glucose infusion, which provides novel insight into physiological mechanisms associating nutrition and reproductive function in dairy cows. However, as in our previous research effort (Vieira et al., 2010), caution must be applied when extrapolating the results reported herein to lactating dairy cows given that the physiological and metabolic aspects associated with parturition, resumption of reproductive function, and milk synthesis were not accounted for in the present experimental model. In addition, milk yield capacity is considered moderate to low in Gir × Holstein cattle (Madalena et al., 1979); hence, the animals used herein might not fully represent the physiological aspects of a high-producing Holstein cow.

\section{REFERENCES}

Arthington, J. D., and L. R. Corah. 1995. Liver biopsy procedures for determining the trace mineral status in beef cows. Part II. (Video, AI 9134). Extension TV, Dept. Commun., Coop. Ext. Serv., Kansas State Univ., Manhattan.

Butler, W. R. 2005. Inhibition of ovulation in the postpartum cow and the lactating sow. Livest. Prod. Sci. 98:5-12.

Curley, K. O., Jr., D. A. Neuendorff, A. W. Lewis, J. J. Cleere, T. H. Welsh Jr., and R. D. Randel. 2008. Functional characteristics of the bovine hypothalamic-pituitary-adrenal axis vary with temperament. Horm. Behav. 53:20-27.

FASS. 1999. Guide for the Care and Use of Agricultural Animals in Agricultural Research and Teaching. 1st rev. ed. Fed. Anim. Sci. Soc., Champaign, IL.

Fleige, S., and M. W. Pfaffl. 2006. RNA integrity and the effect on the real-time qRT-PCR performance. Mol. Aspects Med. 27:126-139.

Kim, S. K., and R. F. Novak. 2007. The role of intracellular signaling in insulin-mediated regulation of drug metabolizing enzyme gene and protein expression. Pharmacol. Ther. 113:88-120.

Lemley, C. O., S. T. Butler, W. R. Butler, and M. E. Wilson. 2008 Short communication: Insulin alters hepatic progesterone catabolic enzymes cytochrome P450 2C and 3A in dairy cows. J. Dairy Sci. 91:641-645.

Lemley, C. O., T. A. Wilmoth, L. R. Tager, K. M. Krause, and M. E. Wilson. 2010. Effect of a high cornstarch diet on hepatic cytochrome $\mathrm{P} 4502 \mathrm{C}$ and $3 \mathrm{~A}$ activity and progesterone half-life in dairy cows. J. Dairy Sci. 93:1012-1021.

Lucy, M. C. 2001. Reproductive loss in high-producing dairy cattle: Where will end? J. Dairy Sci. 84:1277-1293.

Machado, M. F., V. M. Portela, C. A. Price, I. B. Costa, P. Ripamonte, R. L. Amorim, and J. Buratini Jr. 2009. Regulation and action of fibroblast growth factor 17 in bovine follicles. J. Endocrinol. 202:347-353

Madalena, F. E., M. L. Martinez, and A. F. Freitas. 1979. Lactation curves of Holstein-Friesian and Holstein-Friesian $\times$ Gir cows. Anim. Prod. 29:101-107.

Martínez-Jiménez, C. P., J. V. Castell, M. J. Gomez-Lechon, and R. Jover. 2006. Transcriptional activation of CYP2C9, CYP1A1, and CYP1A2 by hepatocyte nuclear factor $4 \alpha$ requires coactivators peroxisomal proliferator activated receptor- $\gamma$ coactivator $1 \alpha$ and steroid receptor coactivator 1. Mol. Pharmacol. 70:1681-1692.

Moriel, P. T. S. Scatena, O. G. Sá Filho, R. F. Cooke, and J. L. M. Vasconcelos. 2008. Concentrations of progesterone and insulin in serum of nonlactating dairy cows in response to carbohydrate source and processing. J. Dairy Sci. 91:4616-4621.

Murray, M. 1991. Microsomal cytochrome P450-dependent steroid metabolism in male sheep liver. Quantitative importance of 63-hydroxylation and evidence for the involvement of a P450 from the IIIA subfamily in the pathway. J. Steroid Biochem. Mol. Biol. 38:611-619.

Nussey, S. S., and S. A. Whitehead. 2001. Endocrinology: An Integrated Approach. Bios Scientific, Oxford, UK.

Ocón-Grove, O. M., F. N. T. Cooke, I. M. Alvarez, S. E. Johnson, T. L. Ott, and A. D. Ealy. 2008. Ovine endometrial expression of fibroblast growth factor (FGF) 2 and conceptus expression of FGF receptors during early pregnancy. Domest. Anim. Endocrinol. 34:135-145.

Spencer, T. E., and F. W. Bazer. 2002. Biology of progesterone action during pregnancy recognition and maintenance of pregnancy. Front. Biosci. 7:d1879-d1898.

Spicer, L. J., and S. E. Echternkamp. 1995. The ovarian insulin and insulin-like growth factor system with an emphasis on domestic animals. Domest. Anim. Endocrinol. 12:223-245.

Vasconcelos, J. L. M., S. Sangsritavong, S. J. Tsai, and M. C. Wiltbank. 2003. Acute reduction in serum progesterone concentrations after feed intake in dairy cows. Theriogenology 60:795-807.

Vendramini, J. M. B., L. E. Sollenberger, J. C. B. Dubeux Jr. S. M. Interrante, R. L. Stewart Jr., and J. D. Arthington. 2008. Sward management effects on forage component responses in a production system for early weaned calves. Agron. J. 100:1781-1786.

Vieira, F. V. R., C. N. Lopes, B. I. Cappellozza, A. B. Scarpa, R. F. Cooke, and J. L. M. Vasconcelos. 2010. Effects of intravenous glucose infusion and nutritional balance on serum concentrations of NEFA, glucose, insulin, and progesterone in non-lactating dairy cows. J. Dairy Sci. 93:3047-3055.

Wettemann, R. P. C. A. Lents, N. H. Ciccioli, F. J. White, and I. Rubio. 2003. Nutritional- and suckling-mediated anovulation in beef cows. J. Anim. Sci. 81(Suppl. 2):E48-E59.

Wildman, E. E., G. M. Jones, P. E. Wagner, R. L. Boman, H. F. Troutt, and T. N. Lesch. 1982. A dairy cow body condition scoring system and its relationship to selected production characteristics. J. Dairy Sci. 65:495-501. 